\title{
Appendiceal Cancer TNM Finding v7
}

National Cancer Institute

\section{Source}

National Cancer Institute. Appendiceal Cancer TNM Finding v7. NCI Thesaurus. Code C89891.

A finding about one or more characteristics of appendiceal cancer, following the rules of the TNM AJCC v7 classification system. Carcinomas and carcinoid tumors of the appendix are included, but are separately categorized. (from AJCC 7th Ed.) 